\title{
Pengaruh Karakteristik Rumah Tangga, Keragaman Makanan, Lingkungan Hidup terhadap Status Gizi Balita
}

\author{
The Impact of Household Characteristics, Dietary Diversity, the Environment \\ on the Nutritional Status of Children Under Five
}

\author{
Fitria Nur Rahmawati", Tri Mulyaningsih, Akhmad Daerobi \\ Fakultas Ekonomi dan Bisnis, Universitas Sebelas Maret, Surakarta, Indonesia \\ ("fitrie.rahma@gmail.com)
}

\begin{abstract}
ABSTRAK
Rumah tangga atau keluarga merupakan tempat anak-anak untuk memaksimalkan pertumbuhan dan perkembangan serta memenuhi gizi mereka, guna menciptakan kualitas sumber daya manusia unggul dan menjadi pendorong pertumbuhan ekonomi Negara yang akan datang. Penelitian ini bertujuan untuk mengkaji faktor karakteristik sosial ekonomi rumah tangga, keragaman makanan, dan lingkungan hidup serta pengaruhnya terhadap status gizi balita di Indonesia. Penelitian ini menggunakan rancangan cross sectional dan menggunakan data sekunder dari Indonesia Family Live Survey (IFLS) gelombang 5 (IFLS5). IFLS merupakan survei longitudinal dari sampel acak sekitar $83 \%$ penduduk di Indonesia pada tahun 1993. Sampel dalam penelitian ini adalah anak berusia 0-60 bulan (balita) yang berjumlah 4.670 balita. Metode penelitian menggunakan Model Regresi Multinomial Logistik. Hasil penelitian menunjukkan bahwa status gizi balita dipengaruhi oleh pendapatan keluarga, pendidikan ibu, jenis kelamin balita, wilayah tempat tinggal, akses pada air minum dan sanitasi yang baik. Kesimpulannya adalah pendidikan ibu sangat berpengaruh signifikan terhadap tiga status gizi balita, yaitu gizi buruk, gizi kurang, maupun gizi lebih. Kata kunci: Status gizi, sosial ekonomi, keragaman makanan, air, sanitasi
\end{abstract}

\section{ABSTRACT}

The household or family is a place for children to maximize their growth and development and fulfill their nutrition, to create high-quality human resources and to drive the country's economic growth for the future. This study aims to examine factors of household socioeconomic characteristics, dietary diversity, and the environment and their effects on the nutritional status of children under five in Indonesia. This study uses cross-sectional design and uses secondary data from Indonesia Family Live Survey (IFLS) wave 5 (IFLS5). IFLS is a longitudinal survey of a random sample of $83 \%$ of the population in Indonesia in 1993. The sample in this study was children aged 0-60 months (toddlers), totaling 4,670 children under five. The research method is to use a multinomial logistic regression model. The results showed that the nutritional status of children under five years old was affected by family income, mother's education, the gender of children under five, residential areas, access to drinking water and good sanitation. The conclusion is that the mother's education has a significant influence on the three nutritional status of children under five, namely wasted, severely wasted, and overweight. Keywords: Nutritional status, socioeconomic, dietary diversity, water, sanitation 


\section{PENDAHULUAN}

Kualitas kesehatan anak-anak secara umum ditentukan oleh latar belakang rumah tangga atau keluarga. Pertumbuhan dan perkembangan anak-anak dipengaruhi oleh keluarga mereka. Menangani status gizi anak, keluarga mereka memiliki peran yang sangat penting. ${ }^{1,2}$ Lingkungan keluarga merupakan tempat anakanak untuk memaksimalkan pertumbuhan dan perkembangan serta memenuhi gizi mereka. Keluarga dengan fungsi keluarga yang sesuai dan ikatan emosional yang baik dapat mendukung pertumbuhan dan perkembangan anakanak mereka. ${ }^{1,3}$ Berdasarkan penelitian sebelumnya tentang pola pengasuhan keluarga dan status gizi, ditemukan bahwa pengasuhan keluarga yang baik memiliki korelasi positif dengan status gizi anak. ${ }^{4}$ Keluarga merupakan kelompok yang memiliki peran penting dalam proses pengembangan, pencegahan, serta perbaikan setiap masalah kesehatan yang ditemukan didalam keluarga. ${ }^{5}$

Masalah gizi lebih rentan dialami oleh anak-anak. Oleh sebab itu, mereka membutuhkan asupan nutrisi yang lebih tinggi dibandingkan dengan orang dewasa. Anak-anak akan menderita kekurangan gizi jika mereka tidak dapat mengakses gizi dalam jumlah yang cukup dan seimbang. Malnutrisi adalah masalah kekurangan gizi dan kelebihan berat badan, yang akan menyebabkan masalah kesehatan, seperti kesakitan, kematian, dan kecacatan. Hal tersebut juga akan menurunkan tingkat produktivitas, menghambat pertumbuhan sel-sel otak yang mengakibatkan ketidaktahuan dan keterbelakangan mental. Terdapat lebih dari 200 juta anak di bawah lima tahun di negara berkembang menderita kekurangan gizi. Kekurangan gizi atau malnutrisi berkontribusi lebih dari setengah dari hampir 12 juta kematian balita di negara-negara berkembang setiap tahun. ${ }^{6}$

Sebagai salah satu negara berkembang, Indonesia juga mengalami masalah anak-anak kurang gizi. Dialaporkan pada tahun 2013, anakanak di bawah lima tahun mengalami gizi buruk $(19,6 \%)$ dan gizi kurang (12\%), sementara mereka yang menderita pengkerdilan berjumlah 32,9\%. ${ }^{7}$ Berdasarkan Rencana Pembangunan Jangka Menengah Nasional (RPJMN) 2015-
2019, Indonesia bertujuan untuk mengurangi proporsi anak-anak yang gizi buruk menjadi $17 \%$, gizi kurang menjadi $9,5 \%$ dan pengkerdilan menjadi $28 \%$ pada tahun 2019. Malnutrisi terjadi akibat kombinasi faktor, yaitu defisiensi dalam hal akses dan kualitas makanan, udara yang tidak memadai, layanan sanitasi dan kesehatan dan layanan perawatan kesehatan yang kurang optimal. ${ }^{8}$

Ditemukan bahwa masalah gizi akut maupun kronis masih terjadi di Indonesia. ${ }^{9}$ Masalah gizi akut di sebagian besar Kabupaten/Kota di Indonesia diperlihatkan oleh masalah kekurangan berat badan (underweight) dan gizi kurang (wasted), sedangkan masalah gizi kronis diperlihatkan oleh masalah kerdil (stunted). Masalah gizi akut juga berkaitan dengan pola asuh ibu terhadap balitanya, pengetahuan ibu yang didapatkan dari proses pendidikan maupun kemampuan mengakses informasi yang diimplementasikan dalam kehidupan sehari-harinya. ${ }^{10}$

Penelitian lain juga menemukan bahwa, di Indonesia kekurangan gizi yang diukur dengan indeks berat badan signifikan dengan gizi buruk. ${ }^{11}$ Penelitian tersebut menemukan bahwa tingkat pendidikan orang tua terutama pendidikan ibu memiliki pengaruh yang signifikan terhadap status gizi anak-anak usia 2-5 tahun. Ditemukan pula hubungan antara pendidikan ibu dan status gizi balita bahwa proporsi gizi kurang pada balita yang mempunyai ibu berpendidikan rendah jauh lebih tinggi daripada yang mempunyai ibu berpendidikan tinggi yaitu $17,9 \%$ dibanding $7,8 \% .{ }^{12}$ Ibu dengan pendidikan yang tinggi cenderung memiliki pengetahuan gizi, kesehatan, dan pengasuhan anak yang lebih baik. ${ }^{13}$ Status gizi balita tergantung pada asupan gizi, tingkat pengetahuan ibu, tingkat ekonomi keluarga, pendidikan ibu, pola asuh dan ketahanan pangan. ${ }^{14}$

Selanjutnya ditemukan pula hubungan antara status ekonomi keluarga dengan status gizi balita. Balita yang tinggal bersama keluarga dengan status ekonomi rendah mempunyai proporsi status gizi kurang yang lebih tinggi dibandingkan dengan balita yang tinggal bersama keluarga dengan status ekonomi tinggi. Persentase gizi kurang balita yang tinggal bersama keluarga dengan status ekonomi rendah se- 
banyak $17,9 \%$ dan gizi kurang pada balita yang tinggal bersama keluarga dengan status ekonomi tinggi sebanyak $7,7 \% .^{12}$

Beberapa literatur menunjukkan bahwa pendidikan ibu dan daerah tempat tinggal sangat mempengaruhi gizi buruk kronis di kalangan anak-anak di Indonesia. ${ }^{15}$ Berdasarkan literatur lainnya, status gizi anak juga dipengaruhi oleh faktor demografi seperti pendidikan orang tua terutama pendidikan ibu dan faktor tempat tinggal. Penelitian terdahulu menemukan bahwa status gizi anak di perkotaan dan pedesaan, menunjukkan bahwa gizi anak di perkotaan lebih baik dibandingkan di pedesaan. ${ }^{16,17,18}$ Ditemukan bahwa kekurangan gizi di Indonesia masih menjadi penyakit kemiskinan, sedangkan kelebihan gizi adalah salah satu kekayaan. ${ }^{19}$ Potensi lainnya yang berkaitan dengan efek dari daerah perkotaan terhadap status gizi adalah kemudahan untuk mengakses bahan pangan, informasi mengenai kesehatan dan gizi, dan memadainya sarana transportasi dan infrastruktur. ${ }^{20}$ Masyarakat di perkotaan memiliki kemudahan akses mememperoleh makanan dan insfrastuktur kesehatan dibandingkan dengan masyarakat pedesaan.

Berikutnya, terdapat faktor lain yaitu kebiasaan makan pada anak-anak yang juga memiliki peran penting dalam menentukan tingkat kesehatan anak. Kebiasaan makan tidak hanya bervariasi dari masing- masing keluarga tetapi juga berubah karena adanya faktor budaya dan sosial ekonomi di masing-masing keluarga. ${ }^{21}$ Terjadi perubahan dengan cepat terkait pola makan pada anak-anak dan prevalensi obesitas di negara maju. Selain itu, terbukti bahwa faktor makanan berkaitan dengan peningkatan risiko penyakit kronis, maka terdapat rekomendasi bahwa konsumsi makanan harus ditingkatkan pada keragaman jenis makanannya. ${ }^{22}$ Kurangnya keragaman jenis makanan merupakan masalah pada negara-negara miskin dan berkembang. Hal tersebut dikarenakan pola makan mereka sebagian besar didasarkan pada makanan pokok bertepung dan sering kali menambahkan sedikit atau tidak sama sekali produk hewani dan sedikit buah-buahan serta sayuran segar.

Faktor lain yang mempengaruhi gizi balita adalah kualitas lingkungan. Penelitian menunjuk- kan bahwa masalah gizi pada bayi dan balita di Indonesia disebabkan oleh infeksi penyakit yang dipicu oleh sanitasi lingkungan yang buruk. ${ }^{23}$ Berdasarkan uraian tersebut di atas, penelitian ini bertujuan untuk mengkaji faktor karakteristik sosial ekonomi rumah tangga, demografi, perilaku konsumsi, dan kualitas lingkungan hidup terhadap status gizi balita di Indonesia. Penelitian ini menjadi menarik dikarenakan penelitian ini menggunakan data yang terbaru dari Indonesia Family Live Survey (IFLS), penelitian ini juga mencakup faktor-faktor yang komprehensif (mencakup faktor dari level individu, level rumah tangga, dan level lingkungan) dari masing-masing sampel penelitian, serta penelitian ini menggunakan metode yang dapat menjelaskan pengaruh dari variabel-variabel kategori terhadap status gizi balita.

\section{BAHAN DAN METODE}

Penelitian ini menggunakan rancangan cross sectional. Datayang digunakan dalam penelitian ini ialah data yang bersumber dari Indonesia Family Live Survey (IFLS) gelombang 5 (IFLS5). Indonesia Family Live Survey (IFLS) merupakan survei longitudinal dari sampel acak rumah tangga yang melibatkan kuesioner dan pengukuran antropometrik. ${ }^{24}$ Survei longitudinal merupakan survei yang dilakukan pada sampel penelitian yang sama selama beberapa periode survei. Survei longitudinal juga merupakan survei yang melibatkan monitoring perkembangan dan/atau perubahan yang terjadi pada sampel penelitian.

Gelombang pertama IFLS (IFLS1) dilakukan pada 1993/1994 oleh RAND bekerja sama dengan Lembaga Demografi, Universitas Indonesia. Gelombang pertama (IFLS1), survei ini mewakili sekitar $83 \%$ penduduk yang tinggal di 13 dari 26 provinsi di Indonesia pada tahun $1993 .{ }^{25}$ IFLS2 dan IFLS2 + dilakukan pada tahun 1997 dan 1998, adalah bekerja sama RAND dengan UCLA dan Lembaga Demografi, Universitas Indonesia. IFLS2 + mencakup 25\% sub-sampel rumah tangga IFLS. Berikutnya, pada IFLS3, yang dilakukan pada tahun 2000 dilakukan oleh RAND bekerja sama dengan pusat Penelitian Kependudukan, Universitas Gadjah Mada. Gelombang keempat IFLS (IFLS4), yang dilakukan pada 2007/2008 
dilakukan atas kerjasama RAND, pusat Studi Kependudukan dan Kebijakan (CPPS) Universitas Gadjah Mada, dan Survey METER. Gelombang kelima dari IFLS (IFLS-5) diterbitkan pada tahun 2014-2015. ${ }^{26}$

Indonesia Family Live Survey (IFLS) yang terbaru adalah gelombang 5 (IFLS5) dilakukan pada tahun 2014-2015, yang diketahui terdapat sebanyak 16.204 rumah tangga dan 50.148 individu yang diwawancarai. Adapun jumlah populasi anak yang berusia 0-60 bulan (balita) sebanyak 5.095 balita yang tinggal di Indonesia pada tahun 2014. Sedangkan jumlah sampel dalam penelitian ini, setelah diolah sesuai dengan kriteria sampel dan yang hanya memenuhi syarat sebanyak 4.670 anak berusia $0-60$ bulan (balita). Analisis hubungan variabel terikat dan bebas dalam penelitian ini menggunakan metode reg- resi logistik. Metode regresi logistik bertujuan untuk melakukan pengujian probabilitas yang kemungkinan muncul atau tidak dalam suatu kejadian. Model regresi respon kualitatif disebut juga dengan model probabilitas. ${ }^{27,28}$ Regresi logistik yang digunakan dalam penelitian ini adalah Model Multinomial Logistik. Model Multinomial Logistik merupakan model logit yang digunakan apabila variabel terikat dan variabel bebas merupakan variabel kategori.

Selanjutnya, dengan menggunakan data dari IFLS gelombang 5 dalam penelitian ini diperoleh data untuk variabel terikat maupun variabel bebas. Variabel terikat dalam penelitian ini adalah kategori $z$-score status gizi balita. Pengkategorian $z$-score status gizi balita dalam penelitian ini dilakukan berdasarkan indeks berat badan menurut umur. Selanjutnya dilakukan perhitungan $z$-score berdasarkan dari Keputusan Menteri Kesehatan Republik Indonesia Nomor 1995/ MENKES/SK/XII/2010 tentang Standar Antropometri Penilaian Status Gizi Anak. ${ }^{29}$ Penelitian ini menggunakan kategori $z$-score status gizi balita yang baik sebagai variabel kontrol.

Berdasarkan dariKeputusan MenteriKesehatan Republik Indonesia Nomor 1995/MENKES/SK/XII/2010 tentang Standar Antropometri Penilaian Status Gizi Anak, jika balita memiliki indeks berat badan menurut umur $(\mathrm{BB} / \mathrm{U})$ pada ambang batas (z-score) $<-3$ SD maka akan masuk dalam kategori gizi buruk. Berikutnya balita dengan termasuk dalam gizi kurang apabila indeks berat badan menurut umur $(\mathrm{BB} / \mathrm{U})$ pada ambang batas (z-score) -3 SD sampai dengan $<-2$ SD. Balita dinyatakan memiliki gizi baik apabila indeks berat badan menurut umur (BB/U) pada ambang batas (z-score) -2 SD sampai dengan 2 SD. Selanjutnya, apabila balita memiliki indeks berat badan menurut umur $(\mathrm{BB} / \mathrm{U})$ pada ambang batas (z-score) $>2 \mathrm{SD}$ dinyatakan dalam kategori gizi lebih.

Sedangkan untuk variabel bebas dalam penelitian ini adalah variabel pendapatan keluarga, pendidikan ibu, tempat tinggal balita, jenis kelamin balita, keragaman makanan, konsumsi air minum, dan sanitasi. Variabel keragaman makanan yang dimaksud ialah jenis makanan pokok yang dikonsumsi oleh balita. Adapun pengkategorian keragaman makanan berdasarkan komponen jenis makanan pokok balita yaitu karbohidrat, protein, sayuran, dan buah. Sedangkan variabel keragaman konsumsi makanan pokok balita dikategorikan menjadi kategori 0 jika tidak makan semua komponen setiap hari, kategori 1 jika makan sedikitnya 1 komponen setiap hari, kategori 2 jika makan sedikitnya 2 komponen setiap hari, kategori 3 jika makan sedikitnya 3 komponen setiap hari, dan kategori 4 jika makan semua komponen setiap hari. Variabel air minum dikategorikan air minum aman dan air minum tidak aman, sedangkan sanitasi dikategorikan sanitas aman dan sanitasi tidak aman.

\section{HASIL}

Berdasarkan data dari Indonesia Family Live Survey gelombang 5, balita yang tinggal di wilayah perkotaan terdapat 2.952 balita (57,94\%), sedangkan 2.143 balita $(42,06 \%)$ tinggal di wilayah pedesaan. Balita yang berjenis kelamin laki-laki sebanyak 2.502 balita $(52,52 \%)$, sedangkan $2.262(47,48 \%)$ balita berjenis kelamin perempuan. Keragaman makanan balita paling banyak pada kategori 2 yaitu balita makan sedikitnya 2 komponen setiap hari yaitu sebanyak $43,12 \%$. Sebagian besar balita mengonsumsi air minum tidak aman $(95,95 \%)$ dan sanitasi lingkungan aman sebesar $(73,72 \%)$ (Tabel 1). Kategori Status gizi balita Indonesia berdasarkan data IFLS gelombang 5 terban- 
Tabel 1. Frekuensi Sampel Berdasarkan Variabel Bebas

\begin{tabular}{lcc}
\hline \multicolumn{1}{c}{ Variabel } & $\mathbf{n}=\mathbf{5 . 0 9 5}$ & $\mathbf{\%}$ \\
\hline Tempat tinggal & & \\
$\quad$ Perkotaan & 2.952 & 57,94 \\
$\quad$ Pedesaan & 2.143 & 42,06 \\
Jenis kelamin & & \\
$\quad$ Laki-laki & 2.676 & 52,52 \\
$\quad$ Perempuan & 2.419 & 47,48 \\
Keragaman makanan & & \\
$\quad$ Kategori 0 & 72 & 1,41 \\
$\quad$ Kategori 1 & 581 & 11,40 \\
$\quad$ Kategori 2 & 2.197 & 43,12 \\
$\quad$ Kategori 3 & 1.528 & 29,99 \\
$\quad$ Kategori 4 & 717 & 14,07 \\
Air minum & & \\
$\quad$ Air minum aman & 206 & 4,04 \\
$\quad$ Air minum tidak aman & 4.889 & 95,95 \\
Sanitasi & & \\
$\quad$ Sanitasi aman & 3.756 & 73,72 \\
$\quad$ Sanitasi tidak aman & 1.339 & 26,28 \\
\hline Sumber : IFLS, 2014 & &
\end{tabular}

Tabel 2. Status Gizi Balita Indonesia Menurut Berat Badan/Umur (BB/U)

\begin{tabular}{lccc}
\hline $\begin{array}{c}\text { Kategori Status } \\
\text { Gizi }\end{array}$ & $\mathbf{n = 5 . 0 9 5}$ & $\mathbf{\%}$ & Kumulatif \\
\hline Gizi Buruk & 76 & 1,49 & 1,49 \\
Gizi Kurang & 553 & 10,85 & 12,35 \\
Gizi Baik & 3.784 & 74,27 & 86,61 \\
Gizi Lebih & 682 & 13,39 & 100,00 \\
\hline
\end{tabular}

Sumber : IFLS, 2014

yak balita kategori gizi baik sebanyak 3.784 $(74,27 \%)$ dan balita yang mengalami gizi buruk $76(1,49 \%)$ (Tabel 2).

Hasil dari pengolahan data menggunakan program Stata 12 dengan jumlah sampel sebanyak 4.670 balita, diperoleh bahwa nilai Prob $>$ chi2 sebesar 0,000 , dengan demikian dapat diartikan bahwa secara serentak variabel bebas (pendapatan keluarga, pendidikan ibu, tempat tinggal balita, jenis kelamin balita, keragaman makanan, konsumsi air minum, dan sanitasi) mempengaruhi variabel terikat (z-score kategori status gizi) pada kategori gizi buruk, gizi kurang, gizi baik, maupun gizi lebih. Hasil pengolahan juga menunjukkan LR chi (18) sebesar 251,19 yang menjelaskan kemampuan model dalam memprediksi variabel terikat (z-score kategori status gizi) (Tabel 3).

\section{PEMBAHASAN}

Pendapatan keluarga memiliki pengaruh dalam menurunkan kemungkinan balita mengalami gizi buruk maupun gizi kurang. Status gizi buruk, pendapatan keluarga memiliki koefisien $(-0,252)$ dengan $P>|z| 0,173$. Hal tersebut berarti bahwa balita yang tinggal dengan keluarga yang memiliki pendapatan lebih tinggi 1 juta rupiah, maka akan menurunkan kemungkinan sebesar $25 \%$ balita tersebut mengalami gizi buruk walaupun tidak secara signifikan. Balita dengan kategori status gizi kurang, menunjukkan pendapatan keluarga memiliki koefisien $(-0,176)$ dengan $P>|z| 0,014$. Hal tersebut berarti balita yang tinggal dengan keluarga yang memiliki pendapatan lebih tinggi 1 juta rupiah, maka akan secara signifikan menurunkan kemungkinan sebesar $17 \%$ balita tersebut mengalami gizi kurang dibandingkan dengan balita yang tinggal pada keluarga berpendapatan lebih redah. ${ }^{11}$

Status gizi lebih, menunjukkan pendapatan keluarga memiliki pengaruh dalam meningkatkan kemungkinan balita mengalami gizi le-bih. Balita yang status gizi lebih, pendapatan keluarga memiliki koefisien 0,460 dengan $\mathrm{P}>|\mathrm{z}| 0,000$. Hal tersebut berarti bahwa balita yang tinggal dengan keluarga yang memiliki pendapatan lebih tinggi 1 juta rupiah, maka akan secara signifikan meningkatkan kemungkinan sebesar $46 \%$ balita tersebut mengalami gizi lebih dibandingkan dengan balita yang tinggal pada keluarga yang berpendapatan lebih rendah. ${ }^{11}$

Berikutnya, berdasarkan hasil pengolahan data menunjukkan pula bahwa pendidikan ibu memiliki pengaruh signifikan dalam menurunkan kemungkinan balita mengalami gizi buruk maupun gizi kurang. Semakin lama ibu menempuh pendidikan maka akan signifikan mengurangi kemungkinan 5,9\% balita mengalami gizi buruk. Sementara itu, semakin lama ibu menempuh pendidikan maka akan signifikan mengurangi kemungkinan $2,9 \%$ balita mengalami gizi kurang. Sedangkan pada status gizi lebih, lama ibu menempuh pendidikan akan signifikan pada peningkatan kemungkinan balita mengalami gizi lebih. Setiap peningkatan 1 tahun ibu menempuh pendidikan, maka akan menaikkan kemung- 
Tabel 3. Hasil Pengolahan Data dengan Model Regresi Multinomial Logistik

\begin{tabular}{|c|c|c|c|c|c|}
\hline Z score kategori status gizi & Coef. & Std. Err. & $\mathbf{z}$ & $\mathbf{P}>|\mathbf{z}|$ & 95\% Conf. \\
\hline \multicolumn{6}{|l|}{ Gizi Buruk } \\
\hline Pendapatan keluarga & $-0,252$ & 0,185 & $-1,36$ & 0,173 & $-0,615$ \\
\hline Pendidikan ibu & $-0,059$ & 0,028 & $-2,10$ & 0,036 & $-0,115$ \\
\hline Dummy perkotaan & $-0,319$ & 0,247 & $-1,29$ & 0,197 & $-0,804$ \\
\hline Dummy laki-laki & 0,246 & 0,238 & 1,03 & 0,302 & $-0,221$ \\
\hline \multicolumn{6}{|l|}{ Keragaman makanan } \\
\hline Kategori 1 & $-0,260$ & 1,082 & $-0,24$ & 0,810 & $-2,382$ \\
\hline Kategori 2 & $-0,033$ & 1,030 & $-0,03$ & 0,974 & $-2,052$ \\
\hline Kategori 3 & $-0,215$ & 1,044 & $-0,21$ & 0,837 & $-2,261$ \\
\hline Kategori 4 & 1,085 & 1,036 & 1,05 & 0,295 & $-0,945$ \\
\hline Air minum aman & $-0,659$ & 0,454 & $-1,45$ & 0,147 & $-1,549$ \\
\hline Sanitasi aman & $-0,164$ & 0,260 & $-0,63$ & 0,527 & $-0,675$ \\
\hline Cons__ & 0,963 & 2,862 & 0,34 & 0,736 & $-4,647$ \\
\hline \multicolumn{6}{|l|}{ Gizi Kurang } \\
\hline Pendapatan keluarga & $-0,176$ & 0,071 & $-2,47$ & 0,014 & $-0,317$ \\
\hline Pendidikan ibu & $-0,029$ & 0,011 & $-2,64$ & 0,008 & $-0,051$ \\
\hline Dummy perkotaan & -0110 & 0,096 & $-1,14$ & 0,253 & $-0,299$ \\
\hline Dummy laki-laki & 0,212 & 0,093 & 2,29 & 0,022 & 0,030 \\
\hline \multicolumn{6}{|l|}{ Keragaman makanan } \\
\hline Kategori 1 & $-0,220$ & 0,388 & $-0,57$ & 0,571 & $-0,982$ \\
\hline Kategori 2 & $-0,186$ & 0,371 & $-0,50$ & 0,616 & $-0,915$ \\
\hline Kategori 3 & $-0,052$ & 0,373 & $-0,14$ & 0,889 & $-0,785$ \\
\hline Kategori 4 & $-0,327$ & 0,394 & $-0,83$ & 0,407 & $-1,101$ \\
\hline Air minum aman & $-0,594$ & 0,209 & $-2,83$ & 0,005 & $-1,005$ \\
\hline Sanitasi aman & $-0,070$ & 0,107 & $-0,66$ & 0,510 & $-0,280$ \\
\hline Cons_ & 1,676 & 1,102 & 1,52 & 0,129 & $-0,485$ \\
\hline \multicolumn{6}{|l|}{ Gizi Lebih } \\
\hline Pendapatan keluarga & 0,460 & 0,078 & 5,88 & 0,000 & 0,307 \\
\hline Pendidikan ibu & 0,044 & 0,014 & 3,15 & 0,002 & 0,016 \\
\hline Dummy perkotaan & 0,374 & 0,129 & 2,89 & 0,004 & 0,120 \\
\hline Dummy laki-laki & 0,151 & 0,115 & 1,31 & 0,189 & $-0,074$ \\
\hline \multicolumn{6}{|l|}{ Keragaman makanan } \\
\hline Kategori 1 & $-0,081$ & 0,469 & $-0,17$ & 0,861 & $-1,001$ \\
\hline Kategori 2 & $-0,603$ & 0,452 & $-1,33$ & 0,182 & $-1,489$ \\
\hline Kategori 3 & $-0,681$ & 0,456 & $-1,49$ & 0,135 & $-1,576$ \\
\hline Kategori 4 & 0,230 & 0,461 & 0,50 & 0,618 & $-0,673$ \\
\hline Air minum aman & 1,076 & 0,720 & 1,49 & 0,135 & $-0,336$ \\
\hline Sanitasi aman & 0,530 & 0,175 & 3,02 & 0,003 & 0,186 \\
\hline Cons__ & $-11,149$ & 1,401 & -795 & 0,000 & $-13,896$ \\
\hline
\end{tabular}

Number of observation $\quad 4.670$

LR chi (18) 251,19

Prob $>$ chi2 0,0000

Pseudo R2 0,0387

Log likelihood $\quad-3116,2038$

Sumber: Data Sekunder IFLS, 2014

kinan balita akan mengalami gizi lebih sebesar $4,4 \%{ }^{10,11,12}$

Sedangkan pada status gizi buruk menunjukkan bahwa koefisien dummy perkotaan sebesar (-0,319) dengan $\mathrm{P}>|\mathrm{z}| 0,197$. Hal terse- but menerangkan bahwa balita yang tinggal di wilayah perkotaan akan mengurangi kemungkinan memiliki gizi buruk, walaupun tidak secara signifikan. Balita yang tinggal di wilayah perkotaan akan 38\% mengurangi kemungkinan 
balita mengalami gizi buruk dibandingkan dengan balita yang tinggal di wilayah pedesaan. Berikutnya pada status gizi kurang menunjukkan bahwa koefisien dummy perkotaan sebesar $(-0,110)$ dengan $\mathrm{P}>|\mathrm{z}| 0,253$. Hal tersebut menerangkan bahwa balita yang tinggal di wilayah perkotaan akan mengurangi kemungkinan memiliki gizi kurang, walaupun tidak secara siginifikan. Balita yang tinggal di wilayah perkotaan akan $14 \%$ mengurangi kemungkinan balita mengalami gizi kurang dibandingkan dengan balita yang tinggal di wilayah pedesaan.

Selanjutnya, pada status gizi lebih menunjukkan bahwa koefisen dummy perkotaan sebesar 0,374 dengan $\mathrm{P}>|\mathrm{z}| 0,004$. Hal tersebut menerangkan bahwa balita yang tinggal di wilayah perkotaan akan meningkatkan kemungkinan memiliki gizi lebih secara signifikan. Balita yang tinggal di wilayah perkotaan akan 37\% memiliki kemungkin gizi lebih secara signifikan dibandingkan dengan balita yang tinggal di wilayah pedesaan. ${ }^{15,16,17}$

Penelitian ini juga menemukan bahwa koefisien dummy laki-laki pada status gizi buruk menunjukkan 0,246 dengan $\mathrm{P}>|\mathrm{z}| 0,302$. Hal tersebut berarti bahwa balita yang berjenis kelamin laki-laki akan menambah kemungkinan memiliki gizi buruk, walaupun tidak secara signifikan. Balita yang berjenis kelamin laki-laki memiliki kemungkinan $24 \%$ berstatus gizi buruk dibandingkan balita yang berjenis kelamin perempuan. Sedangkan pada status gizi kurang menunjukkan bahwa koefisien dummy laki-laki sebesar 0,212 dengan $\mathrm{P}>|\mathrm{Z}| 0,022$. Hal tersebut berarti bahwa balita yang berjenis laki-laki akan menambah kemungkinan memiliki gizi kurang, walaupun tidak secara signifikan. Balita yang berjenis kelamin laki-laki memiliki kemungkinan $21 \%$ berstatus gizi kurang dibandingkan balita yang berjenis kelamin perempuan.

Berikutnya pada status gizi lebih menunjukkan bahwa koefisien dummy laki-laki sebesar 0,151 dengan $\mathrm{P}>|\mathrm{z}| 0,189$. Hal tersebut menunjukkan bahwa balita yang berjenis kelamin laki-laki memiliki 15\% kemungkinan berstatus gizi lebih dibandingkan dengan balita yang berjenis kelamin perempuan.

Sedangkan faktor keragaman makanan pada status gizi buruk, balita yang mengonsum- si makanan kategori 1, 2, dan 3 (makan sedikitnya 1, 2, dan 3 komponen setiap hari) akan mengurangi peluang memiliki gizi buruk dibandingkan balita pada kategori 0 (tidak makan semua komponen setiap hari), walaupun tidak secara signifikan. Sedangkan balita yang mengonsumsi makanan kategori 4 (makan sedikitnya 4 komponen setiap hari) akan menambah peluang memiliki gizi buruk dibandingkan balita pada kategori 0 (tidak makan semua komponen setiap hari), tetapi tidak secara siginifikan. Berikutnya pada status gizi kurang, balita yang mengonsumsi makanan kategori 1, 2, 3, dan 4 (makan sedikitnya 1, 2, 3, 4 komponen setiap hari) akan mengurangi peluang memiliki gizi kurang dibandingkan balita pada kategori 0 (tidak makan semua komponen setiap hari).

Sedangkan pada status gizi lebih, balita yang mengonsumsi makanan kategori $1,2,3$, dan 4 (makan sedikitnya 1, 2, 3, komponen setiap hari) akan mengurangi peluang memiliki gizi lebih dibandingkan balita pada kategori 0 (tidak makan semua komponen setiap hari). Namun, apabila balita mengonsumsi makanan kategori 4 (makan sedikitnya 4 komponen setiap hari) akan menambah peluang $23 \%$ memiliki gizi lebih, walaupun tidak secara signifikan. ${ }^{20,21}$

Air minum yang aman akan mengurangi $65 \%$ peluang balitamemilikigiziburuk. Selanjutnya, air minum yang aman akan mengurangi secara siginifikan peluang sebesar $59 \%$ balita memiliki gizi kurang dibandingkan dengan balita yang mengkonsumsi air minum tidak aman. Sedangkan pada status gizi lebih, air minum yang aman akan meningkatkan peluang balita memiliki gizi lebih, walaupun secara tidak signifikan. ${ }^{22}$

Penelitian ini juga menemukan bahwa, sanitasi yang aman akan mengurangi $16 \%$ peluang balita memiliki gizi buruk dan $7 \%$ peluang balita memiliki gizi kurang. Sedangkan pada status gizi lebih, sanitasi yang aman akan meningkatkan secara signifikan peluang sebesar 53\% balita memiliki gizi lebih, dibandingkan dengan balita yang memiliki sanitasi tidak aman. ${ }^{22}$

\section{KESIMPULAN DAN SARAN}

Berdasarkan pembahasan, dengan diasumsikan semua variabel lainnya dalam mo- 
del tidak berubah atau konstan, sehingga dapat disimpulkan bahwa balita dapat menurunkan peluang memiliki gizi buruk dan gizi kurang apabila balita tersebut tinggal dengan keluarga yang berpendapatan tinggi, memiliki ibu yang berpendidikan lebih lama, tinggal diwilayah perkotaan, mengonsumsi makanan yang beragam,mengonsumsi air minum yang aman, danmemiliki akses terhadap sanitasi yang aman. Berikutnya, dengan diasumsikan semua variabel lainnya dalam model tidak berubah atau konstan, sehingga dapat disimpulkan bahwa balita dapat meningkatkan peluang memiliki gizi lebih apabila balita tersebut tinggal dengan keluarga yang berpendapatan tinggi, memiliki ibu yang berpendidikan lebih lama, tinggal diwilayah perkotaan, mengonsumsi makanan yang beragam, mengonsumsi air minum yang aman, dan memiliki akses terhadap sanitasi yang aman.

Penelitian ini juga menemukan bahwa, balita yang berjenis kelamin laki-laki menunjukkan lebih berpeluang mengalami gizi buruk, gizi kurang, maupun gizi lebih dibandingkan dengan balita yang berjenis kelamin perempuan. Terkait status gizi balita perlu adanya fokus peningkatan dan pendampingan gizi terutama terhadap balita yang berjenis kelamin laki-laki, dengan tanpa mengabaikan gizi balita perempuan. Selanjutnya, perlu adanya upaya untuk meningkatkan derajat kesehatan dan status gizi masyarakat melalui upaya pemberdayaan masyarakat. Hal tersebut dapat dilakukan melalui peningkatan pengetahuan ibu tentang gizi dapat dimulai dari penyuluhan tentang gizi di posyandu dan puskesmas. Air minum yang aman dan sanitasi yang aman penting untuk meningkatkan status gizi anak-anak. Sehingga, rumah tangga harus mewaspadai kebersihan air minum serta meningkatkan kebersihan lingkungan, yaitu dengan menjaga lingkungan air dan mengelola limbah rumah tangga dengan benar.

\section{DAFTAR PUSTAKA}

1. Soetjiningsih. Tumbuh Kembang Anak. Jakarta: Buku Kedokteran EGC; 2012.

2. Notoatmodjo, S. Prinsip-Prinsip Dasar Ilmu Kesehatan Masyarakat. Jakarta: Rineka Cipta; 2003.

3. Almatsier, S. Prinsip Dasar Ilmu Gizi. Ja- karta: PT Gramedia Pustaka Utama; 2010.

4. Khasanah, U. Hubungan Pola Asuh dan Karakteristik Keluarga dengan Status Gizi pada Anak Usia Sekolah di SD Negeri Kelurahan Tugu Kota Depok. [Tesis]. Depok: Universitas Indonesia; 2012.

5. Sutikno, E., \& Al, E. Hubungan antara Fungsi Keluarga dan Kualitas Hidup. Jurnal Kedokteran Indonesia. 2011:2(1).

6. UNICEF. The State of the World'S Children 1998 (Focus on Nutrition). New York: Oxford University Press; 1998.

7. Rakerkesnas Regional Barat. Kebijakan Perencanaan Pembagunan Kesehatan dan Gizi (RPJMN 2015-2019/Perpres No 2/2015). Batam: Kementerian PPN/ Bappenas; 2015.

8. UNICEF. Progress For Children Achieving the MDGs with Equity. New York; 2010.

9. Ananta, A., \& Hatmadji, S. H. Mutu Modal Manusia: Suatu Analisis Pendahuluan. Jakarta: LDE Universitas Indonesia; 1985.

10. Ulfani, D. H., Martianto, D., \& Baliwati, Y. F. Faktor-Faktor Sosial Ekonomi dan Kesehatan Masyarakat Kaitannya dengan Masalah Gizi Underweight, Stunted, dan Wasted di Indonesia: Pendekatan Ekologi Gizi. Journal of Nutrition and Food. 2011: 6(1);59-65.

11. Skoufias, E. Parental Education and child Nutrition in Indonesia. Bulletin of Indonesian Economic Studies. 1999:35(1);99119.

12. Indarti, Y. Hubungan Status Ekonomi Keluarga dengan Status Gizi Balita di Kecamatan Ajung Kabupaten Jember Tahun 2016. Jurnal Fenomena. 2016:15(1);149162.

13. Rahmariza, E., Tanziha, I., \& Sukandar, D. Analisis Determinan Karakteristik Keluarga dan Pemenuhan Hak Kesehatan Anak serta Dampaknya terhadap Status Gizi. Jurnal MKMI. 2016:12(3);153-160.

14. Burhani, P. A., Oenzil, F., \& Revilla, G. Artikel Penelitian Hubungan Tingkat Pengetahuan Ibu dan Tingkat Ekonomi Keluarga Nelayan dengan Status Gizi Balita di Kelurahan Air Tawar Barat Kota Padang. Jurnal Kesehatan Andalas. 2016:5(3);515-521. 
15. Sumarto, S., \& Silva, I. De. (2015). Child Malnutrition in Indonesia: Can Education, Sanitation and Healthcare Augment the Role of Income?. MPRA Paper. 2015: 66631;1-58.

16. Fatima, O. N. Comparative Study of Nutritional Status of Perkotaan and Pedesaan School Girl's Children Khartoum State, Sudan. in. Journal of Science and Technology. 2011:12(December);60-68.

17. Laus, M. F., Miranda, V. P. N., Almeida, S. S., Costa, T. M. B., \& Ferreira, M. E. C. Geographic Location, Sex and Nutritional Status Play an Important Role in Body Image Concerns Among Brazilian Adolescents. Journal of Health Psychology. 2013:18(3);332-338.

18. Md. Serajul Islam, Jakia Sultana Jothi, Monirul Islam, O. H. Nutritional Status of Pedesaan and Perkotaan Under-Five Children in Tangail District, Bangladesh. International Journal of Innovation and Applied Studie. 2014:8(2);841-848.

19. Hanandita, W., \& Tampubolon, G. The double burden of malnutrition in Indonesia: Social determinants and geographical variations. SSM-Population Health. 2015:1(Desember);16-25.

20. H, O. W. K., Raharjo, B. B., Nugroho, E., \& Hermawati, B. (2017). Sumber Daya Lokal Sebagai Dasar Perencanaan Program Gizi Daerah Perkotaan. Jurnal MKMI. 2017:13(1);1-11.

21. Sekiyama, M., Roosita, K., \& Ryutaro, O. Snack Foods Consumption Contributes to Poor Nutrition of Pedesaan Children in West Java, Indonesia. Asia Pacific Journal Clinic Nutrition. 2012:21(4);558-567.

22. Ruel, M. Is Dietary Diversity an Indica- tor of Food Security or Dietary Quality? a Review of Measurement Issues and Research Needs. Food Nutrition Bulletin. 2003:24(2);231

23. Hidayat, T. S., \& Fuada, N. Hubungan Sanitasi Lingkungan, Morbiditas dan Status Gizi Balita di Indonesia. Penelitian Gizi dan Makanan. 2011:34(2);104-113.

24. Rachmi, C. N., Agho, K. E., Li, M., \& Baur, L. A. Stunting, Underweight and Overweight in Children Aged 2.0-4.9 Years in Indonesia: Prevalence Trends and Associated Risk Factors. Plos One. 2016:1-17. Available at: http://doi.org/10.1371/journal.pone. 015475 .

25. RAND. The Indonesia Family Life Survey (IFLS). Available at: https://www.rand.org/ well-being/social-and-behavioral-policy/ data/FLS/IFLS.html.

26. Strauss, J., Witoelar, F., \& Sikoki, B. (2016). The Fifth Wave of the Indonesia Family Life Survey: Overview and Field Report. [Working Paper].2016;1(1). Available at: https://www.rand.org/content/ dam/rand/pubs/working_papers/WR1100/ WR1143z1/RAND_WR1143z1.pdf.

27. Gujarati, D. N., \& Porter, D. C. Basic Econometrics (5th ed.). The McGraw-Hill Series;2009.

28. Field, A. Discovering Statistics using SPSS (2nd edition). London: Sage Publications Ltd;2005. Available at: http://doi. org/10.1348/000709906X100611.

29. Menteri Kesehatan Republik Indonesia. Keputusan Menteri Kesehatan Republik Indonesia Nomor:1995/MENKES/SK/ XII/2010 Tentang Standar Antropometri Penilaian Status Gizi Anak; 2011. 